\title{
School and Immigration: Welcoming Literature
}

\author{
Teresa Colomer Martínez, Universitat Autònoma de Barcelona
}

(Article received 5 September $2012^{1}$; final version received 14 September 2012)

\begin{abstract}
This article outlines the advantages of using literature to aid the transition into the host country for newly arrived children and to help establish a bridge between their identities and their reading skills, communicative capacities and the demands of school. Criteria are offered on the best books to be shared with classmates that will help them join in with the school work while shared intercultural education. The article discusses activities that are especially suitable in the classroom, such as ones based on orality and interpretation of narratives, supported by strong visual components. It highlights teacher-guided group discussions as a means of scaffolding linguistic and interpretative skills for beginners as well as for the literacy education of all the students in the classroom.
\end{abstract}

\section{Why literature?}

M. It is titled "Immigrants" 2 . Do you know what that means?

G. Us, we come from Romania and come into another country. That's what it is, immigrants. ${ }^{3}$

M. Se titula "Emigrantes" ¿sabéis que significa?

G. Nosotros, que venimos de Rumanía y entramos en otro país. Es eso, emigrantes

(Original text)

The starting point to answer the question 'why literature' is to think that literature is a powerful educational tool that can create a new representation of current societies, including diversity of backgrounds and cultures. Many elements of the imagination concerning a culture are transmitted through literature. In literature, a set of symbols and cultural references are produced that help children build their awareness of belonging to a broad spectrum of identities, ranging from their own culture to being a part of wider humanity. There are overlapping layers, without any established order, which come about through lived differences and tensions that exist between these levels. In this process of growing awareness, literature provides a privileged tool to articulate the combination of cultural identities of each person, and shows that the more experience is rooted in a particular culture, the more universal it becomes.

In recent years the effect of literary education in the process of social integration has begun to be analyzed. Michèle Petit (1999), for example, began his research based on the question of what literary reading means for young immigrants in the Paris suburbs. The results of the study revealed that the literature had offered to young people 
both a wide exposure to language, as well as nexus of conjugation of their identities. They also noted significant problems, for instance, the tension that emerged within the same immigrant community concerning children growing reading habits, demonstrating that some were fearful that reading might separate the children from their origins, or, the negative perception of the school host solutions towards the newly arrived: the interventions were seen as a means of marginalization and would limit their possibilities of integration and social advancement.

\section{The context of a plural society}

Current changes in our societies oblige us to face the challenge of a new understanding of 'us' that does not imply 'not-them' (in the pun used by the philosopher Xavier Rubert de Ventós). The educational use of literature for this task is not immediately clear. Just as any planning decisions about language teaching in schools, the use of literature in education derives from the social project wishing to promote it. From political science models and results of the experiences of different countries are studied. These models, which examine, for instance, periodic revolts of immigrant French teenagers or the feeling of marginalization of second or third generation youth which has alarmed British or Dutch host societies can be fruitful. Thus, multicultural models have moved from the notion of assimilation (wherein the concept of immigration is not very high) to that of integration (based on assimilation in the public sphere and cultural multiplicity in the private sphere) and, more recently, to accommodation (public recognition of specific cultural traits).

For a time, terms referring to personal attitudes such as "tolerance" or "mutual understanding", or social aspects such as "multiculturalism" and "interculturalism", were seen as magic words to help ward off conflicts in schools that inevitably arise in the classrooms. However these are terms that encompass very different social models with very different educational consequences. The transition from one social model to another is inevitably filled with gaps given that the process occurs at the same time tension augments according to the degree the host societies feel threatened in their own values and identities. As far back as the ancient Greeks it was believed that there were only two solutions to addressing conflicts of coexistence: the polis, that is, institutional reforms, and paideia, referring to education focused on shared social norms. 


\section{Small decisions in school practice}

The consequences of adopting a particular model of coexistence can lead to very specific outcomes. The simple choice of reading materials in a school where students come from diverse cultural backgrounds has already been the cause of endless problematic discussions between teachers:

a) Problems of ideological content in texts that reflect various conflicts and prejudices (Moors and Christians, conquerors and indigenous persons, etc.), raising yet again inescapable value judgments concerning the historical perspective of the texts, just as occurred at other the times with issues such as racism or gender, all of which may leads to repression of proposed reading in an absurd twist of political correctness. Still, it is possible to come up with activities that take into account these conflicts, for example through contrastive analysis of conflicting perspectives related different texts (the holy war taken from the Koran and a text by Orlando Furioso, for example), or by simply comparing the different means of naming such as "crusades" in Christianity and "Frank invasions" in Muslim texts).

b) Quantitative problems in addressing diversity, given that the number of texts is necessarily limited -which children will enjoy the presence of literature of their native culture in class and which will not? How will the lack of familiarity with certain texts and authors being read in the class affect family involvement when it comes to homework? Formulas can be found for exploration of texts according to common traits, such as myths and other traditional oral literature, and the use of reading groups made up of students from diverse backgrounds in order to accommodate the multiplicity of the classroom; also establishing small rotating reading activities or storytelling, which may even the children's family members, thus allowing equal protagonism to everyone.

c) There may also be qualitative problems in maintaining balance between knowledge and empowerment of the culture of origin and the host culture. There is inevitable variance of levels of literacy among newly arrived students who may use languages with alphabets different from the host school language or be accustomed to using symbols or sinographs; also knowledge of audiovisual fiction and technology varies widely, just as cultural references and forms of narrative vary. This influences the familiarity (or non-familiarity) of literary and fictional forms and for some students, a 
bridge to cover the gaps they may have in respect to the host school's educational curriculum is needed.

Considerable thought should be dedicated to the above issues, paying attention to not ignore them as if no chance of problems existed, something which is a common temptation for power-holders.

\section{The use of children's books}

The view of literature as a vehicle for cultural understanding of the world and of other cultures has always been an upheld value in children's literature. In the thirties, Paul Hazard spoke of the "republic of children" as a universal literary space, and after the Second World War, the idea of educating for "never again" concerning confrontation between social groups led to a large number of books with such values. The evolution of our societies has created a new wave of books in this line. Last century, in the 1980s, the issue of multiculturalism emerged with force, especially in Anglo-Saxon countries. Books, articles, training programs readers, etc. soon abounded in the United States aimed at making the literature of diverse communities visible and to foster acceptance of coexistence. But limitations to the adopted approach were soon identified. The writer Hazel Rochman had this to say about it:

[M]ulticulturalism means across cultures, against borders; and multiculturalism doesn't mean only people of color. Multiculturalism isn't a special subject of an anthology or a separate area of a library, or a special month of the year, or a special view of history. It's part of everything we do. It's us. (...) [T]he best books can make a difference in building community. They can break down borders. And the way that they do that is not with role models and recipes, not with noble messages about the human family, but with enthralling stories that make us imagine the lives of others. A good story lets you know people as individuals in all their particularity and conflict; and once you see someone as a person - their meanness and their courage - then you've reached beyond stereotype. (Rochman, 1995: Against Borders, para. 14)

Types of children's books that are most helpful:

Multilingual books. These offer not only classroom material, they can serve as a link to school learning, in collaboration with the immigrant families, although the degree of literacy within that environment must also be taken into account.

Translations and anthologies. There has been a dramatic increase in edited stories from around the world, especially the compilation of oral traditions from each place, aimed at 
giving voice and cultural recognition to communities of origin.

Books with updated social representations of characters and situations. Sensitivity to "politically correct" teaching presents problems of tending to sterilize the literary quality of the texts, but at the same time it has had the beneficial effect of making the diversity in fiction more common and familiar.

Books on immigration issues. The emergence of this theme, reflecting current social phenomena, has produced some very interesting work in various genres of children's literature, especially picture books and young adult novels.

Books based on orality. Drama texts, songs, folklore anthologies, poems, etc. often combine brevity and play with various linguistic components (phonemes, syntactic structures, etc.). Additionally, there is an increasing amount of resources increasingly available on the Internet.

Books based on imagery. Picture books, graphic narratives or multimodal texts in the Internet may overlap with some of the above categories as a means of facilitating understanding for children who do not yet speak the host language.

Example: 10 picture books to be considered ${ }^{4}$ :

Francotte, Pascale: Lejos de mi país. Barcelona: La Galera.

Greder, Amin: La isla. Salamenca: Lóguez.

Lofthouse, Liz: Ziba vino en un barco. Il. Robert Ingpen. Salamanca. Lóguez.

Müller, Jörg: El soldadito de plomo. Salamanca: Lóguez.

Piquemal, Michel: Mi miel, mi dulzura. Il.Ëlodie Nouhen. Zaragoza: Edelvives.

Recorvits, Helen: Me llamo Yoon. Il. Gabi Swiatkowska. Barcelona: Juventud.

Schimel, L.: !Vamos a ver a papá!. Il.A.M.Rivera. Barcelona: Ekaré.

Sellier, Marie: África, pequeño Chaka. Il. Marion Lesage. Zaragoza: Edelvives.

Sís, Peter: Madlenka. Barcelona: Lumen.

Tan, Shaun: Emigrantes. Barcelona: Barbara Fiore.

\section{Activities full of possibilities}

C. (...) because the person who dies also leaves and you just have to get over it (...) when you come here you have to get over the fact that you're not in your country, and you're terrified.

C. porque la persona que muere también te deja y tienes que superarlo (...) cuando vienes aquí tienes que superar que ya no estás en tu país, y tú estás aterrorizado.

(Original text)

Newly arrived children begin with a sense of being without roots and must reconstruct their identity in a new context and literature appears to be an effective aid through the 
effect of emotional involvement and symbolic elaboration. Literature can contribute to the learning of the host country's language, by combining language learning with cultural learning because the stories, in the words of Perry Nodelman:

push readers toward ideas about what is culturally acceptable of who they are by privileging the perspective from which the events are told (...) in other words, it allows us to see and understand the events and people the way in which the narrator invites us to do so. (1996: 116-118)

Logically, when learning a new language, literary activities based on oral activities are especially useful during the reception process for newcomers:

- Oral storytelling and use of folklore (songs, poems, tongue twisters, etc..).

- Dramatization of short texts.

- Collective discussions about the meaning of stories.

These activities can be done concretely through the use of picture books. In this case, the teaching sequences are more effective if started with a skimming of the book individually or in pairs, in order to give children time to form some idea of the storyline.

Picture albums are particularly suitable for the following reasons:

- Pictures break the barrier of words and makes access to the narrative more equitable for everyone.

- The stories provoke an emotional high that stimulates thinking and desire to communicate, and users will try to use appropriate language forms to express these thoughts. The impulse to communicate surpasses the natural fear of making mistakes; reading becomes more interpretive and more exploratory language is used. Thus, for example, there will be an increase in frequency of words like think, because, probably, perhaps, forms of deduction like then so ... that means ... and making assumptions such as perhaps the author thinks that ... the character must not know that ..., etc.

- Some picture album topics favor the exchange of perspectives between young newcomers and the host school children as seen in the following example of a discussion about book and the issue of immigration. Two young newcomers discuss with a classmate whether he can imagine the situation of local immigrants:

C: Let's see, I don't think so because, because for example if you are in the same country and someone comes to school, you don't know what that person feels, what he feels in his heart, what's inside of his heart when he left his family and friends back there and has to get used to here and can not speak, you don't know how that person feels, well, you can imagine, but not very

B.: it's not the same to imagine it as to feel it.

well. 
C: a ver que, yo pienso que no porque, porque por ejemplo si tú estás en el mismo país y alguien viene a la escuela, pues tú no sabes lo que siente esa persona, lo que, siente su corazón, lo que hay adentro de su corazón cuando ha dejado a su familia y a sus amigos ahí y tiene que acostumbrarse y no sabe hablar, no sabes cómo se siente esa persona, bueno, puedes imaginártelo, pero no muy bien.

B.: no es lo mismo imaginar que sentir.

(original text)

- The existence of picture books with some complexity, aimed at readers in primary or even secondary school, allows students access literary works that might normally challenge their interpretive ability, even if the text provides little or no involvement of newcomers.

- The activities applied to picture books offered many opportunities for educational performance: choose a picture and justify it, photocopy a page and write in the margins the meaning of the imagery, use multiple creative tasks that encourage involvement and exchange, act out the story through the use of language structures, dialogues and vocabulary from the book, etc. Carrying out small shared tasks is especially convenient when the children have a similar beginning level of the language, since these require some linguistic communication skills for the interpretive discussion.

- Discussion of the picture book facilitates both metaliterary enunciation (title, character, perspective, etc.), and the use of external cultural references to explanations, especially the use of audiovisual media that are familiar for children of different countries. This helps the newcomers feel that the school work is within their capabilities, since they can use their own knowledge and acquire other knowledge in a shared and a well-defined territory.

The figure of the teacher as mediator of the discussion is essential. As in any classroom discussion aimed at facilitating learning, the way in which questions are given and how the conversation is guided will determine the quantity and quality of responses. For example:

- If the main concern is with the acquisition of oral proficiency and children are asked about themselves (their tastes, their experiences) instead of questions focusing on the text, you can get lively discussions, but the book will have served a simple trigger, which is then immediately abandoned as an activity guide. The discussion then turns away from the text, leaving untapped literary possibilities of the text, and the possibilities for children to learn to read is left aside. 
- Direct and closed questions (what it is, what happens, etc..) limit responses to literal answer while open questions (why?, tell me, what do you remember?, what does it mean?, how do you know?) will foster inferential answers. This type of response increases when the children are not asked directly, instead the answer emerges through cooperative dialogue in which participants are developing responses together or when responses are obtained through shared tasks about the book. In both cases, children are inclined to give more elaborate responses, as this type of activity provides them a tool to both argue their judgments based on personal experience or through interpretation of the images or textual elements chosen.

- If, at some point, a summary of the discussion of the story plot is given to the students, this yields a powerful resource for learning about the processes of interpretation during the act of reading. Students can then see their collective response objectified and enriched and become aware of having made sense in their responses, which is an obvious bonus.

- By collecting and expanding on specific children's responses provides a form of scaffolding similar to the process of early childhood language learning. It is, therefore, very effective, as long as teachers provide some level of approval and reassurance about what the children have said, so that students are encouraged to continue to respond without fear in exploring further their interpretative hypotheses.

\section{Conclusion}

The use of literature provides ample opportunities for newly arrived children engaged in the process of combining their identities while bridging the gap between their reading and communicative skills and the demands of school. There are many appropriate books on the market that can be shared with their classmates, which can be combined with their school work while fostering a common intercultural education. There are many particularly suitable learning activities for the classrooms, based on oral narratives and visual interpretation of texts. The teacher guiding group discussions can provide appropriate linguistic and interpretive scaffolding, not only for newcomers but for the reading and literacy education of all the students in the classroom.

\section{References}

Nodeman, P. (1996). Illustration and picture books. In P.Hunt (Ed.): International companion encyclopedia of children's literature, pp.116-118. London: Routledge. 
Petit, M. (1999). Nuevos acercamientos a los jóvenes y a la lectura. México: Fondo de Cultura Económica.

Rochman, H. (1995). Against borders. The Horn Book Magazine (online), marzo-abril, Last retrieved 16 September 2012 from http://archive.hbook.com/magazine/articles/1990_96/mar95_rochman.asp

\footnotetext{
${ }^{1}$ This article first appeared as a report in the website of the Spanish Ministry of Education: leer.es. It has been translated into English by Melinda Dooly.

${ }^{2}$ The original title of the book is "The Arrival", which has been translated to "Emigrantes" in the Spanish version.

3 Quotations on children's conversations relate to investigations and 2007/ARIE/00003 EDU200802131/EDUC GRETEL Group (UAB) on the use of picture books during the reception of newcomers. Those reproduced here are, specifically in Fittipaldi, M. (2008): Travesías Textuales: Inmigración y Lectura de Imágenes. Trabajo final de Máster. Dirección Teresa Colomer. Departament de Didàctica de la llengua, de la literatura i de les CCSS. UAB.

${ }^{4}$ Some of these titles are available in several of the official languages in Spain.
}

\begin{abstract}
Author's Reference:
Teresa Colomer Martínez is professor at the Department of the Didactics of the Language, Literature and Social Sciences at the Autonomous University of Barcelona. She directs the GRETEL research group, which studies the relationship between reading, contemporary books for children and youth, and literacy learning in compulsory education. She has a B.A. in Spanish and Catalan Philology and a PhD in Educational Sciences. Professor Colomer is the author of approximately 200 publications concerning these themes. Dr. Colomer is currently directing the international M.A. on Books and Literature for Children and Youngsters (organised by the UAB, the Banco del Libro from Venezuela, and the Germán Sánchez Ruipérez and Santa María foundations), as well as the official interuniversity M.A. on School Library and Reading Promotion (UAB-UB). She has promoted pioneering initiatives in Spain such as the first network of university research on children's literature in Spain (1999-2006), for which she has received several awards. She is a member of numerous councils for educational magazines and holds various courses and conferences on teacher training both in Spain and abroad, particularly in Latin America.
\end{abstract}

Email: teresa.colomer@uab.cat

To cite this article:

Colomer Martínez, T. (2012). School and immigration: Welcoming literature. Bellaterra Journal of Teaching \& Learning Language \& Literature, 5(3), 1-9. 